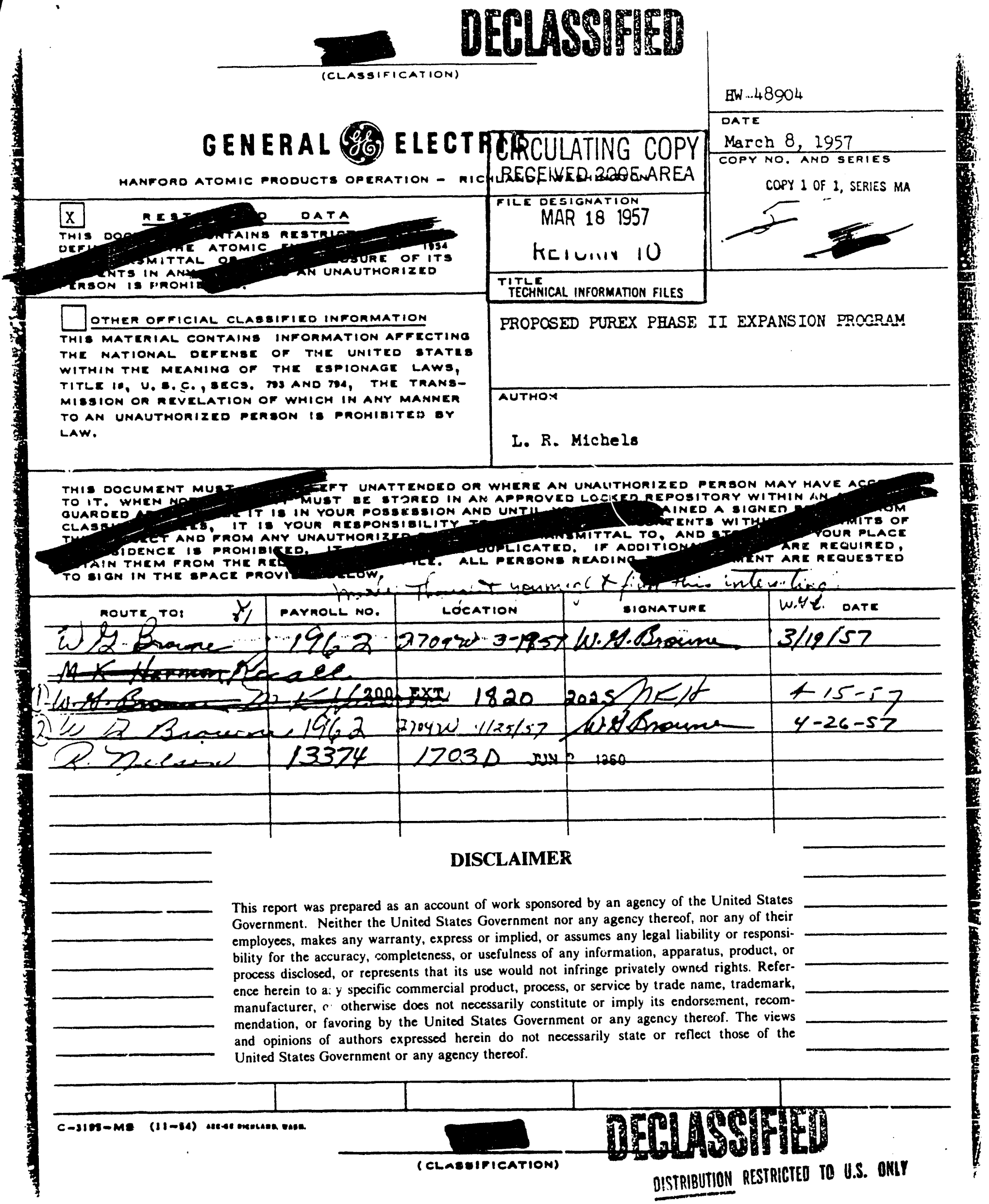




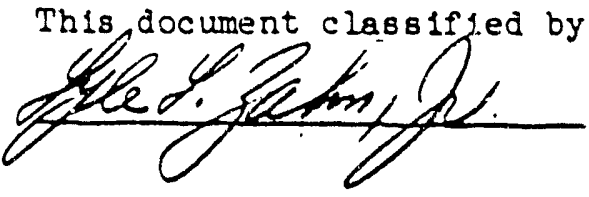

This document consists of

7 pages. No. 5 or coples. Series

BY

L. R. Michels

March 8, 1957

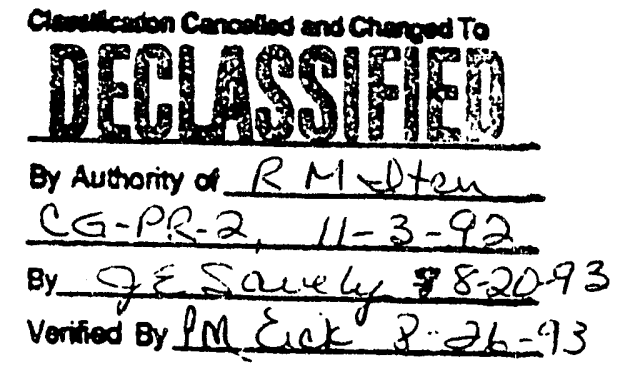

Extraction Des1gn \& Development

Fac1lities Engineering Operation CHEMICAL PROCESSINC DEPARTMENT

General Electric Compeny - Banford Atomlc Products Operation

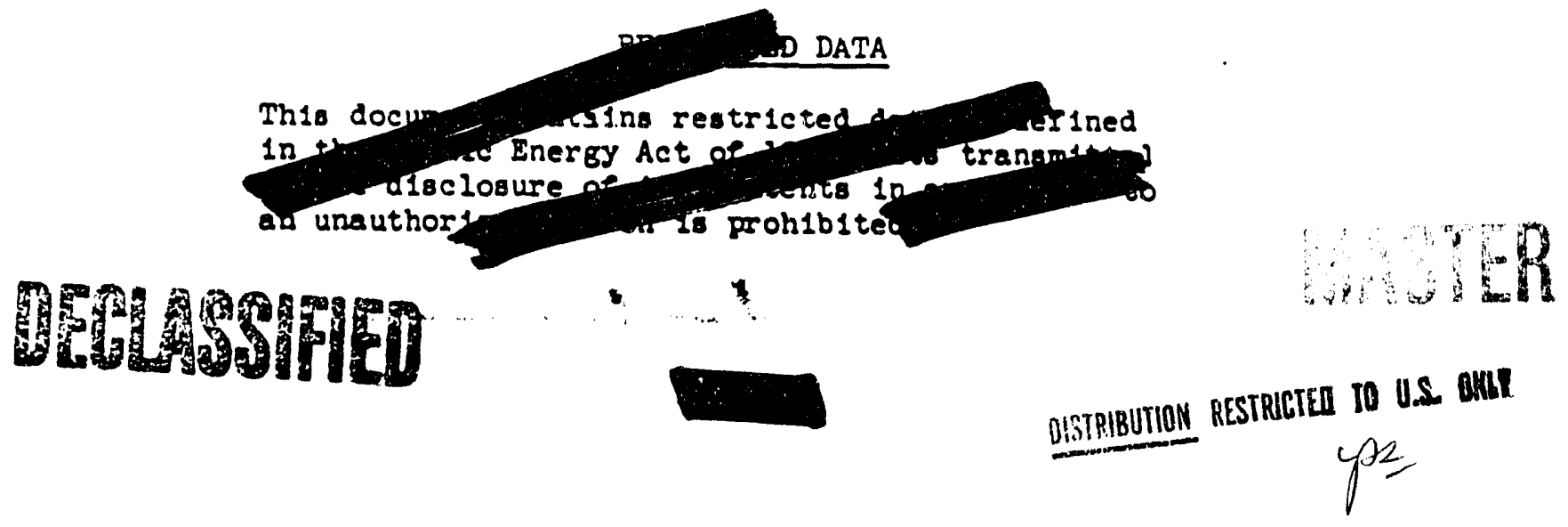


1. O. F. Beaulieu

2. C. R. Bergdahl

3. J. M. Blackburn

4. A. Braciway

5. W. G. Brown

6. V.R. Chapman

7. J. B. Fecht

8. K. G. Griam

9. D. R. Gustavson

10. E. R. Irisb

11. C. E. Kent

12. W. K. MacCready

13. L. R. Nichels

14. E. L. Reed

15. R. B. Rlchards

16. O. C. 8chroeder

17. H. P. Shaw

18. R. E. Tomlinson

19. J. B. Warrea

20. I. H. Zahn

21. 300 File

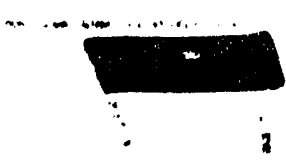


L. I.. Zahn, Supervisor

Extraction Des1gn \& Development

271-T Bldg., 200-W Area

\section{PROPOSED PUREX PHASE II EXPANSION PROGRAM}

References: 1. EW-47889, "Purex Plant Phase II Proposed Flowsheet", by ER Ir 1sh, dated February 1, 1957.

2. HW-48336, 'Budget Study Report, FY-1959 Plant and Equipment Budget, Separations Plant Expansion, Budget Item No. 659-023", by In M1obels, dated February $6,1957$.

Th1s letter sumarizes the results of preliminary studies on the stepwlse expansion of Purex facilities to the ultimate rate of 4.0 capacity factor, using the two-cycle flowsheet of Reference 1. Brlefly, $1 \mathrm{t}$ is $\mathrm{s}$ uggested that Purex be expanded to the intermediate capac1ty of 3.5 capac1ty factor us lng avallable FY-1958 funds 1nsorar as poss1ble; decision to expand Plisex to 4.0 capacity factor can be deferfed for subsequent budgetary consideration.

As delineated in Reference 2, expansion of Purex to 4.0 capac1ty factor would enta1l a total project cost of about $\$ 3,000,000$; beneflc1al use could not be achleved prior to August 1959, due in part to the ava1lab1l1ty of funds of only $\$ 2,000,000$ in the FY1958 budget to flnance the expansion of $202-\mathrm{A}$ Bu1la1ng fac1l1t1es.

The attached F1gure I and Tables I to III, Inclus1re, present data on the cost and scheduling to achleve 2.75 and $3.5 \mathrm{C} . \mathrm{F}$. rates w1th two-cycle operation. The above capacity factors are only approximate because of ancertalnties in extraction colum flooding data. Briefly, the minlmum cost to convert to deasonable two-cycle operat1on vould be about $\$ 800,000$, w1th benef1c1al use date of about Apr 11 1958. Follow1ng this changeover, the capacity of Purex would be between 2.5 and 3.0 C.F. and rould be limited by the $2 A$ Colum. The next logical expansion would require the replacemst of the IBX, $2 B S, I C$ and $2 A$ Columns (1D addition to $B A$ and $B C$ ) and would be IImited by 2E Colum capac1ty to about 3.5 capac1ty factor. The cost for achieving the $3.5 \mathrm{C} . \mathrm{F}$. rate would be about $\$ 2,150,000$; a beneflelal use date of January 1959 would be possible if the fac1lity vere financed with $\mathbf{Y}-1958$ funds.

The 1ncremental cost savings for two-cyele operation orer present three-cycle operstion are estimated at about $\$ 400$ per ton, attributed to 1rproved product recovery and decreased use of essential materials, ut1l1ties and waste storage capac1ty. At a Purex 2.75 capacity factor, monthly sav1ags of about $\$ 225,000$ could be real1zed through twocycle operation. Th1s large cost incentire dictates complet1on of those port1ons or design, procurement and constructson assoclated with changeover to a two-cyolo procese in aivance of project completing of those phases of the Installation assoc1ated atrletly with capac1ty factor 1ncrease. On this bas1s, benefle1al use date of Apr 11 1958 could be realized for tro-cycle oparation.

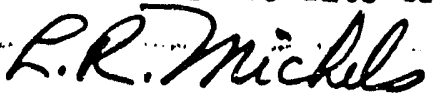

Extract10n Des1ga \& Derelopment

Fac1l1t1es Englneering

IR Michelo: jes

CHEMICAL PROCESSING DEPARTMENT 


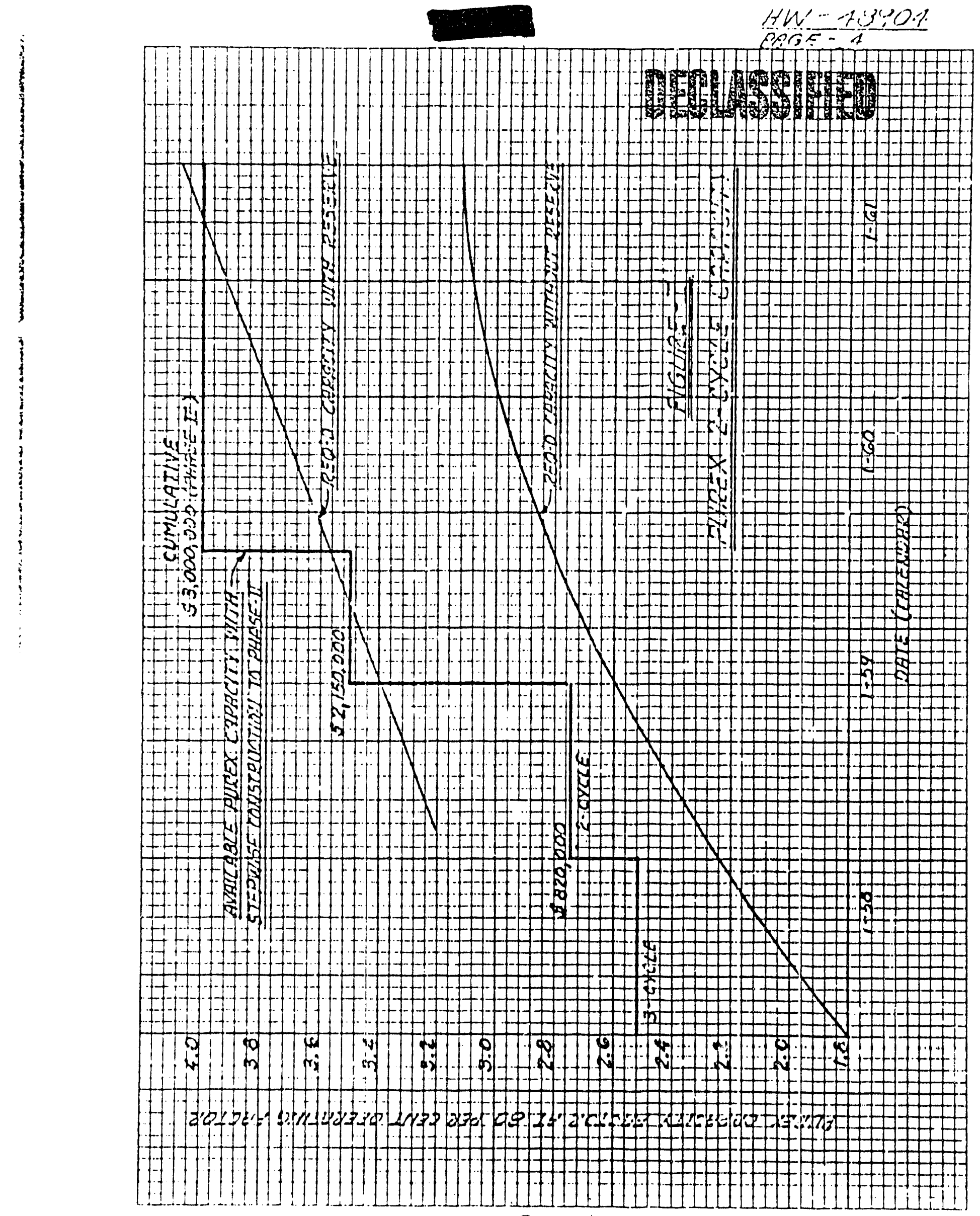


TABLE I

REQUIRED SEPARATIONS PIANT CAPACITY

Tons/Month

\section{U-Metal}

E-Metal

co\% Reserve (on U)

Total with Reserve

Less Redox Phase III

Net, Purex, Including Reserve

Purex capecity factor at $80 \%$

operating efficlency

W1th Reserve

\section{Tons/Month}

$U$ plus E-Metal

Less Redox Phase III

Net, Purex, without Reserve

Purer capacity factor at $80 \%$

operating efficiency

Without Reserve

\begin{tabular}{lrr} 
& DATE \\
\hline $1-59$ & $\frac{1-60}{1-61}$ & $\frac{880}{780}$ \\
50 & 840 & 50 \\
$\frac{156}{980}$ & 50 & $\frac{176}{1106}$ \\
$\frac{300}{686}$ & $\frac{168}{1058}$ & $\frac{300}{806}$
\end{tabular}

$\begin{array}{lll}3.4 & 3.7 & 4.0\end{array}$

$\begin{array}{lll}830 & 890 & 930 \\ \frac{300}{530} & \frac{300}{590} & \frac{300}{630}\end{array}$

$\begin{array}{lll}2.6 & 2.9 & 3.1\end{array}$ 


\section{DECLASSFFED}

TABLE II

TOTAL PROJECT COSTS FOR CONVERSION OF PUREX TO A TWO-CYCLE PROCESS IN ADVANCE OF PHASE II EXPANS ION

I. Inter1m Capac1ty of 2.5 tc 3.0 Capac1ty Factor as I1mited by $2 A$ Column

Changes Required

1. New ES Column plus spare

2. New XaF Tank plus spare

3. Ner Spare IBSI Tank

4. New Jumpers

5. Cold Side Modifications

6. Burlal of IA \& BC Columns and jumpers

Direct Cost iotal Project Cost

$\$ 106,000$

60,000

40,000

143,000

57,000

30,000

\section{Total}

$\$ 436,000$

$\$ 820,000$

II. Inter1m Capec1ty of 3.5 Capecity Factor as I1m1ted by 28 Column

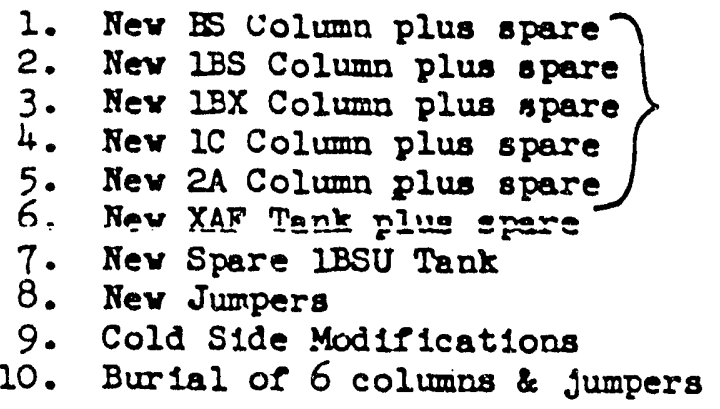

10. Burial of 6 columas \& jumpers

Total
530,000

$\leqslant 0,000$

40,000

390,000

57,000

70,000

$\$ 1,147,000$

$\$ 2,150,000$ 
Project Function

Defin1t1ve Process Des1gn

Start

Complete

Des1gn

Start

Complete

Procurement (Exped1ted Bas18)

Start

Complete

Construction

Start

Complete

Benericlal Uoe

Complete
Schedule Dates Inter 1m Purex Capac1ty Factor

$\begin{array}{lrr}2.5-3.0 & 3.5 & 4.0 \\ \text { Underway } & \text { Underway } & \text { Underway } \\ 8-1-57 & 9-27-57 & 9-27-57\end{array}$

$\begin{array}{rrr}8-1-57 & 8--57 & 8-1-57 \\ 11-15-57 & 12-7-57 & 12-1-57\end{array}$

10-1-57

$10-1-58$

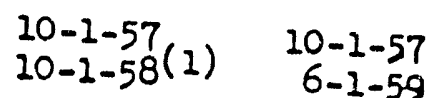

$11-1-57$

$11-1-57$

3-1-59

$1-1-58$

$2-1-59$

10-1-59

$4-1-58$

$1-1-59$

$8-1-59$

(1) Coupletion of procurement by 10-1-58 would expenditure of $\$ 2,150,000$ 1, FY-1958. 

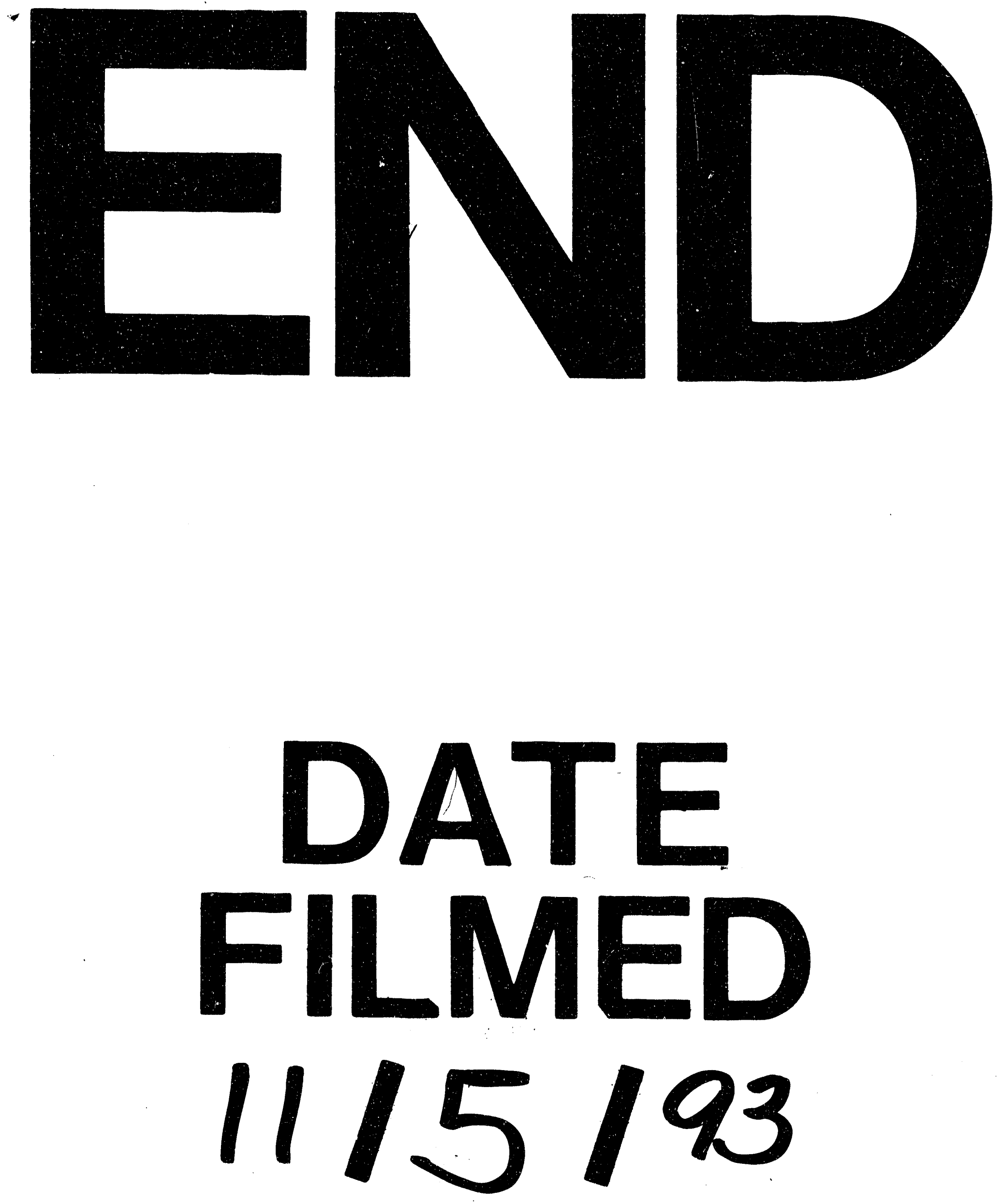
